\title{
A Redacted America: Critiquing the Lack of Transparency at Guantánamo Bay
}

\section{Darshina Dhunnoo}

Department of Political Science, University of Alberta, Edmonton, Alberta

Corresponding author: darshina@ualberta.ca

\section{ABSTRACT}

The willingness to undermine liberal standards of justice and imprisonment has been a major criticism of the detention camp at Guantánamo Bay. The camp's propensity to evade judicial mechanisms offered on American soil is particularly due to its deliberate opacity.

This paper begins with a brief overview of the major arguments in favour of the closure of the facility and the challenges that have prohibited the closure thus far, based on a review of debates and commentary found in investigative reports, legal documents, and scholarly analyses. A substantive portion of this piece will highlight three demonstrable areas where transparency is being detrimentally avoided in the conduct of the Guantánamo Bay detention camp: press access, health care, and the detainee defense counsel. A critique of increasing transparency as a possible impetus to keep the facility open will close the discussion. Ultimately, the transgressions of Guantánamo are so detrimental to American self-conception of liberal values that a correction of the facility's opacity should be but an intermediary step to closing the facility entirely.

Before 2017, the words "safe," "humane," “legal," and "transparent" adorned the frontpage banner of the "Joint Task Force Guantánamo" website,1 a crude rejection of the criticisms of the detention camp at Guantánamo Bay by scholars, non-governmental organizations (NGOs), international institutions and numerous politicians. The camp's propensity to evade the judicial mechanisms offered on American soil is particularly due to its deliberate rejection of transparency in key areas.

This essay begins with a brief explanation of Guantánamo Bay's role in American security politics and an overview of the major arguments both in favour of and against the closure of the facility, based on a review of debates and commentary found in investigative reports, interviews with Guantánamo experts, legal documents, and scholarly analyses. The inaccessibility of the facility to scholars and academics has resulted in the prioritisation of editorial pieces and interviews from those able to access the detention camp in this essay. A substantive portion of this paper will highlight three demonstrable areas where transparency is being avoided: press access, health care, and the detainee defense counsel. A critique of increasing transparency as a possible impetus to keep the facility open will close the discussion. The deliberate obfuscation of transparency at the Guantanamo Bay detention camp is but one representation of a severe transgression of

SPECTRUM INTERDISCIPLINARY UNDERGRADUATE RESEARCH 
purported American liberal values and may illuminate the need to close the facility permanently.

\section{Background}

The detention camp at Guantánamo Bay is an institution established in 2002 by President George W. Bush and the Central Intelligence Agency (CIA) to detain threats to American national security, particularly the suspects behind the 9/11 terrorist attacks. President Bush's 'War on Terror' labeled Guantánamo prisoners as 'unlawful enemy combatants.' This label justified the lack of prisoner protections that would typically be granted to prisoners of war under the Geneva Convention, ${ }^{2}$ and the suspension of habeus corpus, which is the ability for an individual under arrest to hear their charges in court. Instead of the judicial branch of the U.S Government, Guantánamo's trials operate using military commissions, a trial system designed specifically for cases of war. At Guantánamo, military commissions do not meet international fair trial standards and do not offer the same protections as the American federal court, such as the need for a jury to reach consensus, the ability for the accused to view the evidence against them, and the choice of an attorney. ${ }^{3}$

The detainment of over 700 detainees for up to twenty years without trial; the revelation of violent, abusive, and humiliating torture techniques used on detainees in covert CIA "black sites" around the world and on Guantánamo soil; and the cooperation between American institutions and Afghan and Pakistani warlords to entrap suspects demonstrate the United States' capacity to turn the other cheek with regards to extrajudicial and unconstitutional detention while criticizing other nations for human rights violations. ${ }^{4}$ Since 2002, nine detainees have died in custody. ${ }^{5}$ To this day, most detainees at Guantanamo Bay have not been charged with any crimes, and at least $25 \%$ have been declared absolutely innocent. ${ }^{6}$

The very existence of Guantánamo Bay is damning to America's reputation. The use of the Bay as an American base has been contested for decades, even before 9/11. The rhetoric surrounding the CIA's torturous practices, which have been confirmed to include stress positions, sleep and food deprivation, waterboarding, walling, sexual humiliation and the threatening of family members, has led to both the recruitment of Islamic State (IS) soldiers ${ }^{7}$ and by extension the mistreatment of peaceful Muslims in the United States and the Middle East. For President Biden, actionable change begins with increased transparency of current practices at Guantánamo Bay; free access to defense evidence required to conduct fair trials on American soil; repatriation of previously-released individuals; social assistance for released individuals to deter recidivism; and the indefinite closure the facility.

\section{Reasons to Close the Camp}

The motivations to close the detention center at Guantánamo Bay may be summarized in three major areas: international reputation, unreasonable cost, and the ineffective application of American judicial law.

Guantánamo Bay has been used by illiberal regimes in Saudi Arabia, China, and Russia to undermine the American criticisms of their human rights' abuses. ${ }^{8}$ Moazzam Begg, a former Guantánamo detainee and present human rights activist, cites Guantánamo Bay as a rhetorical strategy to recruit IS members. ${ }^{9} \mathrm{He}$ states that the so-called "War on Terror" treats Islamic terrorism as "an exceptional form of violence that necessitates extraordinary interventions," indicating that racism continues to pervade America's counterterrorism programs as long as the facility exists. ${ }^{10}$

As of 2021, the detention centre at Guantánamo Bay costs American taxpayers $\$ 445$ million a year to maintain 40 prisoners and the salaries of 1500-1800 guards. National Public Radio (NPR) estimates that Guantánamo Bay has cost American taxpayers over $\$ 6$ billion dollars from 2002-2020. Only eight men out of the 780 who have been detained at Guantanamo since 2002 have been convicted (four of which have been overturned). Of the forty that remain detained in 2020 , only ten are suspected of having direct ties to Al-Qaeda and other terrorist groups. They are still 
awaiting trial. ${ }^{11}$

The criminality of the Guantánamo detainees has been questioned since 2004, with no documentation existing of $\mathrm{ClA}$-extracted information from the interrogation of these detainees actually assisting in the capture of Osama bin Laden or preventing further terrorist attacks. ${ }^{12}$ Further criticisms of the military commission's efficacy and transparency will be discussed later in this paper as further indictments of the institutions' failures.

\section{Resistance to Closing Guantánamo}

The closure of Guantánamo Bay would require moving military commissions to mainland American soil, which changes the legal liberties prosecutors benefit from on the contested space of Guantánamo Bay. Numerous Republican senators have insinuated to their supporters that moving the $9 / 11$ commissions to American soil would increase the threat of radical Islamist terrorism through proximity to the accused. In reality, it is more likely that American courts would find defendants in these commissions guilty, and that reticence to granting detainees trials on American soil suggests both a distrust of the American judicial system and an Islamophobic perception that certain individuals are unworthy of American justice. ${ }^{13}$

Another challenge with moving detainees to the mainland to be prosecuted in the mainstream justice system is that the CIA's capture, evidence-gathering, and torture practices are considered unconstitutional on American soil. Evidence gathered from detainees through torture may be deemed impermissible, significantly damning the prosecutorial team. ${ }^{14}$ The location of Guantánamo Bay on the Cuban island bypasses these constitutional concerns. The Economist explains that keeping detainees in "legal limbo" is justifiable in the eyes of many Americans, because the detainees are "deemed too dangerous to ever be set free, but whose jihadist activities [are] apparently too shadowy to provide evidence to secure convictions in court."15
Removing detainees from American soil and bases altogether also presents a significant challenge. President Barack Obama's repatriation envoys, tasked to send detainees back to safe locations with the social support systems necessary to restart life and deter recidivism, was terminated by President Donald Trump.

There are broader implications associated with a direct challenge to the U.S. military and CIA's actions to combat terrorism post $9 / 11$. The CIA relies on a lack of transparency to use its black sites - unmarked detention centres notorious for their violent and humiliating interrogation methods - as it did with the capture of Guantánamo detainees. Closing Guantánamo may invite unwelcome investigation into the operations of these centres, challenging the CIA's jurisdiction.

\section{Opacity At Guantánamo}

The Flimsy Veneer of Press Transparency at Guantánamo Bay

"In the United States, the government holds a storytelling monopoly. The stories it tells of Guantánamo dictate its reality, regardless of whether or not those stories are true ... only when we strive to uncover the whole truth can we claim to have freedom of speech." -Aliana Sheers, Telltale Marks: Looking Beyond Censorship of Guantánamo ${ }^{16}$

Numerous first-hand accounts from journalists describe the highly restricted access to Guantánamo Bay. An in-person visit to the facility involves tight schedules, strict monitoring of reporter whereabouts, the signing of a dense "Media Ground Rules" document, ${ }^{17}$ a detailed review of all pictures and video captured in the premises, and an ever-changing slate of rules regarding which buildings journalists will be taken to at any particular time. ${ }^{18}$ Questions are often deflected, with their answers being classified as "protected information." "Protected information," as listed in the ground rules, is defined as "sensitive but unclassified information about friendly intentions, 
capabilities, and activities needed by adversaries to plan and act effectively against friendly mission accomplishment."19

Carol Rosenberg's guided tour of the facility for the Miami Herald illuminates the carefully curated image that the US Military paints about life at Guantánamo. Her tour, like that of all journalists, is orchestrated by the Troopers of the Joint Task Force for Guantánamo's Public Affairs Media Relations Department, designed to "protect both the guard force and the detainees" while "ensuring operational security." ${ }^{20}$ Camp 6, which holds the most cooperative detainees and includes Guantánamo's communal living area is most accessible to reporters, while the maximum-security Camp 5 is rarely visited. No member of the public has seen Camp 7, which is said to hold the ten 9/11 conspirators, including the notorious Khaleid Sheikh Mohammed, the alleged mastermind behind the attacks on the World Trade Center. ${ }^{21}$

Displayed in the newly updated "Bravo Block" are apparent indicators of care for detainee recreation, including books (several of them written by President Obama), an exercise bike, table tennis, and an Xbox. ${ }^{22}$ Access to detainee artwork and writing as well as the ability to film detainees has not been possible for a few years. The press is, however, permitted full access to the kitchen, where cheerful Filipino labourers display the culturally-sensitive varieties of meals offered to detainees. ${ }^{23}$

Rosenberg notes that the press conference that follows the tour of the facility is mired with predictable talking points and does not comment on previously released detainees. ${ }^{24}$ Another journalist on the tour with Rosenberg remarked that in his less-than twenty-four hours on the base, he was completely unaware of the fact that 15 detainees were being transferred to the United Arab Emirates. His ignorance is a sharp reminder of the total control Guantánamo has over its image. ${ }^{25}$

Press releases from the Joint Task Force are intended to report on the activities in areas that journalists are forbidden from accessing, but these releases are few and far between. Americans may recall that the military at Guantánamo regularly provided media updates on detainee hunger strikes (officially-and euphemistically-called "Iong-term non-religious fasting"), a reporting practice that ended in $2013 .^{26}$ Military proceedings available to the public are also heavily redacted, with written transcripts heavily blacked out and live feeds frequently muted by taking advantage of a 40-second delay to censor information. ${ }^{27}$ Explanations for cut feeds are also unsatisfactory. Saadia Khan, from the NGO Human Rights First, explains that her live feed of a proceeding was cut after just twenty minutes. The silence was excused by an official as a means of saving $\$ 60,000$, despite the cost of flying commission staff and defense teams to Guantánamo being nearly $\$ 180,000$ round-trip. ${ }^{29}$ According to many reporters, the process of attending live feeds on the base is also stymied by procedural and scheduling chaos, making information gathering inconvenient and taxing. ${ }^{29}$

Cancellations of press access is also common. As recently as April 2, 2021, the media invitation for the hearing of Majid Shoukat Khan was suddenly cancelled for unspecified reasons, ${ }^{30}$ preventing journalists from even attempting to report on events at Guantánamo independently.

In addition to the highly redacted information coming from the naval base, the institution frequently uses euphemisms such as "long-term non-religious fasting" instead of "hunger strike," "enhanced interrogation methods" instead of "torture," and "extraordinary rendition" as opposed to "extraterritorial abduction." The strict monitoring of terminology, insinuating practices less dramatic than hunger strikes and torture, further indicate the extreme control the U.S. Military exerts on the public to prevent a transparent examination of the facility.

There is evidence to suggest that an engaged public would hold the facility accountable; as demonstrated by the trial of Abu Wa'el Dhiab in 2014. Cleared for release five years prior to his trial, Dhiab fought to publicize his testimony of abusive force-feeding 
with the help of detainee defense attorney Alka Pradhan. ${ }^{31}$ His public testimony led to the suing of the military commander who refused Dhiab access to his wheelchair, the demand for a court order to have independent medical experts evaluate him, and permission for his physician to be able to use the medical equipment on base for his physicals. Subsequently, evidence of Dhiab's violent cell extractions and force feedings was ordered to be released by Judge Gladys Kessler. Dhiab's testimony shocked many Americans. ${ }^{32}$

Khan argues that transparency for the press at Guantánamo is critical to ensuring justice for the accused detainees, the victims of terrorist attacks, and the American people. In the Dhiab case, Judge Kessler added that openness was "essential to public confidence" and necessary for both the basic fairness and appearance of fairness of the judicial system. ${ }^{33}$ As long as the truth of Guantánamo is limited by the U.S. Military and kept from journalists who aim to share that truth with the American people via unrestricted press access, confidence in the Guantánamo's practices is undermined.

How a Lack of Transparency Leaves Health Care in Limbo

As of April 2021, COVID-19 has prevented virtually all visitation to Guantánamo Bay, from the press to NGOs. ${ }^{34}$ The opacity at Guantánamo Bay may be interfering with the prevention of COVID-19 outbreaks at the facility and the maintenance of an aging detainee population.

COVID-19 reached the naval base in mid-March of 2020. In a letter to the US Secretary of Defense in May 2020, four Democratic senators expressed their concern about the potential spread of COVID-19 amongst detainees, and the ability of the facility to provide adequate medical care during the pandemic and beyond. ${ }^{35}$ The International Red Cross is said to be key to detainee welfare, as they enable "confidential discussions with an independent medical officer. . . and the ability to relay messages to family." 36
Due to the severity of the COVID-19 pandemic, the Red Cross was unable to access the facility for close to ten months. The Red Cross was finally able to return to its schedule of visit the facility every three months in December of 2020. However, delegates faced exaggerated measures when meeting with the detainees, including hooded biohazard jumpsuits and N95 respirators, a mandatory six feet distance, plexiglass barriers, and blasting air conditioning-none of which was conducive to an adequate medical and welfare check-in. As a result, a number of detainees cancelled their appointments with delegates, feeling that it impossible to hold a meaningful conversation. ${ }^{37}$ The inability of the Red Cross to perform their duty practically eliminated what little openness existed at Guantánamo.

Public perception about whether Guantánamo detainees deserve healthcare continues to challenge health provisions at the detention centre. In January 2021, President Biden rescinded his plan to vaccinate the 40 remaining Guantánamo detainees after backlash from the American public. These 40 COVID-19 vaccines would have been amongst the 6,000 vaccines required to inoculate the naval base. These vaccinations would also meet the necessary prerequisite to resume the $9 / 11$ trials. ${ }^{38}$ Poor transparency on the part of the US military with regards to operations at Guantánamo may have contributed to many Americans using the so-called War on Terror narrative to justify their belief that detainess are unworthy of access to health care.

The information coming from the detention centre about positive COVID-19 cases is abysmal. ${ }^{39} 40$ After two positive cases of the virus at Guantánamo, the Pentagon ordered the US Navy to refrain from reporting further cases to maintain "operational security" in April. ${ }^{41}$ In October, there were reports of a "heightened state of health alert" for one week, suggesting an outbreak. ${ }^{42}$ While the Navy announced that it had commenced deep-cleaning measures, social distancing practices, temperature checks, and had six ventilators available, the Joint Task Force did not have a chief medical officer at the base as required by the National Defense Authorization Act. ${ }^{43}$ 
The aforementioned letter to the Department of Defense also cited the age of detainees as an increased risk factor for cardiovascular distress, cancers, and kidney failure. The letter referenced "the mental and physical wounds of torture," which might put the population "at greater risk of serious medical complications of COVID-19." ${ }^{44}$

Concerns about elder and palliative care at Guantánamo Bay are not new. Rosenberg's tour of the facility prior to the pandemic described the plans for a new health clinic with surgical, psychiatric, and radiological suites, a necessity based on the aging detainee population. ${ }^{45}$ In 2011, the American Nurses Association was invited to the naval base to assess the quality of nursing care. According to the subsequent report, transparency about health care provisions at the facility was extremely poor, and the commander on base at the time was unable to answer whether the medical facilities complied with the American Nursing Standards and Code of Ethics. ${ }^{46}$ The Association recommended continued consultation with the Red Cross to improve such conditions, but as transparency decreased, so did updates about whether health care standards were being met. ${ }^{47}$

In response to questions about forced feeding from reporters touring the facility, guards claimed that detainees deliberately kept a low body weight to "benefit them in future legal proceedings," 48 insisting that "feeding via nasal gastric tube is not a punishment [but] a medical procedure." 49 According to Carol Rosenberg, one of the Navy doctors praised the medical care on Guantánamo, stating that it was "on par with that of U.S. forces stationed [at Guantánamo Bay] ... when practicable." The doctor refused to state whether any of the detainees were in critical condition. ${ }^{50}$

Guantánamo Bay's shift into a hospice to cater to aging detainees, notwithstanding the distancing requirements of COVID-19, will be costly. In addition to installing hand bars and wheelchair ramps, the military also plans to provide hip and knee replacements, medications for prediabetes, and possibly dialysis. ${ }^{51}$ Specialists in cardiology, prosthetics, and orthopedics have already been called to the facility, incurring great costs as detainees cannot go to the mainland for MRIs. ${ }^{52}$ If the facility stays open for another 25 years, which is allegedly what commanders have been instructed to prepare for, alterations for hospice care could cost close to $\$ 90$ million. And yet, the otherwise amorphous descriptions of present detainee health from limited press releases continue to shield Americans from the sheer cost of keeping the facility open. ${ }^{53}$

A number of concerns about detainee health have been outlined in this section, including the inability of detainees to take advantage of the welfare measures offered by the Red Cross, the potential spread of COVID-19, the compounded effects of COVID-19 on top of a history of mental and physical torture, and the increasing cost of hospice care as detainees age with chronic illnesses. These concerns have only been identified by persistent journalists which suggests that the actual conditions of detainees may be far from American detention standards. The letter to the Minister of Defense undeniably demonstrates the need to close the facility, as it cannot adequately account for detainee health care.

\section{A Defense Team in Deadlock}

The motto of the Guantánamo military commissions website, "Fairness, Transparency, Justice," sharply contrasts the reality of the court procedures. ${ }^{54}$ The most critical aspect of limited transparency in the judicial context of Guantánamo is the lack of access to evidence for the detainee legal counsel.

Under President Obama, it was found that may of the detainees lacked comprehensive case files with the necessary evidence needed to prosecute them. This is likely due to the destruction of the first black sites where detainees were interrogated and tortured by the CIA, which makes it virtually impossible for the detainee defense team to obtain evidence of torture beyond personal transcripts and dated medical evidence. ${ }^{55}$ At least five of the ten alleged 9/11 conspirators were held by the CIA in black sites for 
four years before arriving at Guantánamo. ${ }^{56}$ The Bush administration argued that interrogation intelligence from this period prevented "over 600 attacks," but the documentation to prove this assertion does not exist. $^{57}$

The evidence against the ten highest-risk detainees at Guantánamo, including Khaleid Sheikh Mohammed, is almost airtight. However, evidence obtained under duress or torture is not admissible in pre-trial hearings. ${ }^{58}$ What results is a deadlock of inadmissible evidence and an American population that is beyond ready for charges to be laid, all stemming from limitations on what defense lawyers can discuss with their clients and what can be revealed from their time at CIA black sites. ${ }^{59}$

In 2015, the American Civil Liberties Union (ACLU) called on Guantánamo Bay to open Periodic Review Board meetings to ensure that the Department of Defense was not unfairly disadvantaging detainees by limiting their defense team's access to prosecutorial evidence. While the ACLU's actions did ensure the defense had access to the necessary materials, the US military was permitted to enact extreme redactions of information. ${ }^{60}$ The ACLU's demand predates that of Human Rights Watch, which demanded that the Department of Defense invite NGOs to observe pre-sentencing hearings alongside the press in 2017. Previously, only NGOs who could send American citizens were invited, but Human Rights Watch argued that this limited the ability for NGOs to ensure impartial transparency and accountability. ${ }^{61}$

A just level of transparency for the defense counsel would involve receiving complete information about detainee interrogation at Guantánamo and the CIA black sites around the world, beyond the single 2014 pre-approved executive summary which was provided as of April 2021. ${ }^{62}$ This information could help undermine prosecutorial statements, which is especially necessary for the detainees on lower rungs of the $9 / 11$ conspirator network and those arrested as minors.
Some might be concerned that defense access to this evidence would be too forgiving to the masterminds of 9/11, like Khaleid Sheikh Mohammed. Jonathan Hafetz argues that this is highly unlikely, as evidence against detainees like Mohammed is overwhelming. However, he also believes that such evidence "should not shortcircuit a defendant's right to obtain information as relevant as the details of his prior torture by the same government seeking to convict and execute him."63 Interestingly, the CIA has shared black site interrogation information before outside of a legal context. Columbia Pictures is said to have received this information in the research and production phase of their 2012 film Zero Dark Thirty, long before the Guantánamo detainee defense counsel. ${ }^{64}$

For many, transparency on the military commissions is not enough. In an open letter to President Biden, seven former detainees from Guantánamo advised that the military commissions be scrapped entirely, and suggested moving detainees still facing charges to American soil where they can be tried in accordance with American law. ${ }^{65}$ Transferring military commissions cases to federal courts would guarantee fair trials for the 26 detainees the United States believes it can keep indefinitely, ${ }^{66}$ facilitate the release of six detainees cleared under the Obama and Trump administrations, and possibly hold those in the CIA who committed acts of torture responsible for their violence. ${ }^{67}$

In a 2012 article for the New York Times, David Schulz argues that the public and defense counsel's right to CIA redacted evidence aligns with the First Amendment, citing "public acceptance of the verdict, accountability for lawyers and judges, and democratic oversight of our government institutions" 68 as sure outcomes of access to the information. Ultimately, the current system at Guantánamo challenges the legitimacy and efficacy of the military commissions and prolongs closure and justice for the victims of terror attacks, including 9/11. 
Could transparency keep Guantánamo open?

In the same article, Schulz writes: "We must be prepared to lay out all the facts, wherever they lead, if we are to demonstrate to the world that the verdicts ultimately rendered at Guantánamo are justifiable." 69 This statement suggests the possibility that a more transparent Guantánamo might legitimize it to the extent that the American public, human rights organizations, and politicians decide to keep the facility open.

Indeed, upon reading criticisms of Guantánamo's opacity in the areas of press access, health, and legal defense, one might assume that increased transparency at the facility would allow it to remain open. Rebecca Adelman's article "Safe, Humane, Legal Transparent: State Visions of Guantánamo Bay" addresses how increased apparent transparency during Obama's presidency may have positively influenced the American perception of the facility. Adelman argues that easily accessible, online, visual representations of the naval base (vetted by the US Government, of course) "privileged a reading of the detention site as essential in the fight against terrorism and the security of the US."70 For a short period after President Bush, Guantánamo was no longer an egregious blight on American foreign policy, as crucial details about its operations were no longer secret. Adelman worries that transparency could be a gateway to normalization, humanizing the detention centre to the extent that the average American accepts rather than rejects it. ${ }^{71}$

Increased transparency could also be weaponized to justify the existence of Guantánamo. In 2015, seven Republican senators demanded transparency from the Obama administration-not on the operations of Guantánamo, but on the risk level and behaviour of detainees set to be released. They cited concerns over the $30 \%$ recidivism rate that ex-detainees had under Obama (although ex-detainees under Bush had close to double the recidivism rate). ${ }^{72}$ Increased transparency based on an appeal to a fear of radical Islamist extremism may outweigh the calls for transparency based on appeals to the humanity and cost-consciousness of the American people.

\section{Conclusion}

The Obama administration guaranteed a commitment to "safe, humane, legal and transparent care and custody of detained enemy combatants" at Guantánamo. ${ }^{73}$ President Trump's erasure of "safe" and "transparent" from Obama's original phrasing resulted in a facility at least as egregious as years past. As a number of the sources in this paper have stated, the censorship of information is crucial to Guantánamo's infrastructure and justifying deviations from the rights of prisoners of war. The careful curation of the reports on the conditions at Guantánamo Bay demonstrates the CIA's willingness and predisposition to controlling public perception about the detainees.

This paper has demonstrated three areas-press accessibility, adequate health care, and the detainee defense counsel-where Guantánamo Bay fails to represent the transparency and justice that should be synonymous with purported American liberal values. It also alludes to the idea that increasing transparency could be a promising first step in the facility's permanent closure. ${ }^{74}$ The lack of accountability on the part of the United States risks the legitimacy of the nation's stance against torture and arbitrary detention, threatening its global standing as a liberal democracy to be emulated. The result of this practice is the maintenance of an institution that conflates justice with revenge. 


\section{Notes}

1. Rebecca A. Adelman, “'Safe, Humane, Legal, Transparent': State Visions of Guantánamo Bay,” Reconstruction: Studies in Contemporary Culture 12, no. 4 (2013): 3.

2. Maha Hilal, "We can't just close Guantánamo Bay Prison, we also have to abolish the injustice that allowed it to exist," Opinion, Business Insider, February 3, 2021.

3. David W. Glazier. "Destined for an Epic Fail: The Problematic Guantanamo Military Commissions," Ohio State Law Journal, no. 75 (2014): 903.

4. John Kirby and Carol Rosenberg, "The Ethics and Politics of Guantánamo Bay," Berkley Center, September 17, 2020, video, 1:00:21.

5. Elise Swain, “It's Still Open: Will the Guantánamo Bay Prison Become a 2020 Issue?” The Intercept, March 3, 2019.

6. Conor Friedersdorf, "Dick Cheney Defends the Torture of Innocents," Politics, The Atlantic, December 15, 2014.

7. Adam Jacobson, “'The True Ugly Face of America': Al Qaeda's Propaganda Use of Guantánamo Bay and Implications for US Counterterrorism," Human Rights First (2015).

8. Elisa Epstein, “Guantánamo's Ugly Taint on US Diplomacy,” Human Rights Watch, February 13, 2020.

9. Moazzam Begg, "Full Address and Q\&A," April 25, 2017, OxfordUnion, video, 57:23.

10. Sacha Pfeiffer, “Guantánamo Has Cost Billions; Whistleblower Alleges 'Gross' Waste,” Investigations, NPR, September 11, 2019.

11. “Guantánamo Remains a Stain on America's Reputation,” The Economist, January 14, 2017.

12. Peter J. Honigsberg, "The Never-Ending Travesty of Guantanamo Bay," interview by Sam Seder, January 1, 2020, The Majority Report w/ Sam Seder, video, 46:28.

13. John Kirby and Carol Rosenberg.

14. Ibid.

15. "Guantánamo Remains a Stain on America's Reputation."

16. Aliana E. Sheers, "Telltale Marks: Looking Beyond Censorship of Guantánamo," Alpenglow: Binghamton University Undergraduate Journal of Research and Creative Activity 6, no. 1 (2020): 1.

17. Justin Merriman, “GITMO Procedures Challenge Military 'Transparency,'” Trib Live, September 4, 2016.

18. John Knefel, "Transparency Is a Catch-22 at Guantánamo Bay," Inverse, June 6, 2016.

19. Carol Rosenberg, "Making Guantánamo Great Again: The Prison’s Media Makeover," Miami Herald (Miami, FL), February 12, 2018.

20. Benjamin Cossel, "PAO Teams with Media to Balance Transparency, Security," US Army, February 28, 2011.

21. Knefel.

22. Rosenberg, "Making Guantánamo Great Again.”

23. Ibid.

24. Cossel.

25. Merriman.

26. Knefel.

27. Rosenberg, "Making Guantánamo Great Again."

28. Saadia H. Khan, "Transparency at Guantánamo, But Not Where It Counts," Human Rights First, August 11, 2015.

29. Ibid. 
30. "Military Commissions Media Invitation Announced CANCELLED for United States v. Majid Shoukat Khan Sentencing Hearing," U.S. Department of Defense, April 2, 2021.

31. Knefel.

32. Alka Pradhan, “OPINION: A Momentous Victory for Justice and Transparency at Guantánamo," Al Jazeera America, October 5, 2014.

33. Ibid.

34. Kirby and Rosenberg.

35. “Warren, Reed, Colleagues Seek Information on DOD Efforts to Prevent COVID-19 Outbreaks at Guantánamo Bay Prison," U.S. Senator Elizabeth Warren of Massachusetts, May 28, 2020.

36. Julia Conley, "Pentagon Secrecy around Covid at Guantánamo Is One More Reason to Shut the Prison, Say Senate Dems," Salon, August 23, 2020.

37. Carol Rosenberg, "Red Cross Faces Barriers in Visit to Guantánamo," The New York Times, December 10, 2020.

38. Carol Rosenberg, "Pentagon Halts Plan to Vaccinate the 40 Detainees at Guantánamo Bay," The New York Times, January 31, 2021.

39. Rosenberg, "Red Cross Faces Barriers."

40. Kirby and Rosenberg.

41. Conley.

42. Rosenberg, "Red Cross Faces Barriers."

43. Conley.

44. Napoleon, Erin. "US Senators Concerned over Potential COVID-19 Outbreak at Guantánamo Bay." Jurist, May 28, 2020.

45. Carol, Rosenberg. “New Conundrum at Guantánamo: Aging Detainees,” The New York Times, April 28, 2019.

46. Kirby and Rosenberg.

47. Rebecca M. Pattern, “Searching for Transparency at Guantánamo Bay,” American Nurse, October 11, 2019.

48. Conley.

49. Rosenberg, "Making Guantánamo Great Again.”

50. Ibid.

51. Rosenberg, "New Conundrum at Guantánamo."

52. Rosenberg, "Red Cross Faces Barriers."

53. Conley.

54. Carol Rosenberg, "The Growing Culture of Secrecy at Guantánamo Bay." The New York Times, April 4, 2020.

55. Rosenberg, "New Conundrum at Guantánamo."

56. Patten.

57. Honigsberg.

58. Epstein.

59. Carol Rosenberg, "9/11 Hearings to Focus on Secrecy, Transparency," Miami Herald (Miami, FL), October 14, 2012.

60. Zak Newman, "Guantánamo Review Board: This Is Not What Transparency Looks Like," American Civil Liberties Union, April 26, 2015.

61. "Joint Letter Regarding Concerns about Lack of Transparency in Guantánamo Proceedings," Human Rights Watch, August 1, 2017. 
62. Jonathan Hafetz, "Torture and Transparency in the Military Commissions," Just Security, February 24, 2016.

63. Ibid.

64. Julian Borger, "CIA Gave Details of 9/11 Suspect's Secret Torture to Film-Makers, Lawyers Say," The Guardian (Manchester, UK), February 22, 2019.

65. Moussa Zemmouri, Mohammed Ould Slahi, Ahmed Errachidi, Sami Al Hajj, Lakhdar Boumediane, Moazzam Begg, and Mansoor Adayfi, “An Open Letter to President Biden About Guantánamo," The New York Review of Books, January 29, 2021.

66. Epstein.

67. Matt Spetalnick, Trevor Hunnicutt, and Phil Stewart, "Biden Launches Review of Guantánamo Prison, Aims to Close It before Leaving Office," Reuters, February 12, 2021.

68. David A. Schultz, "Guantánamo Trials Should Be Open,” The New York Times, April 19, 2012.

69. Ibid.

69. Schulz.

70. Adelman.

71. Ibid.

72. "Scott Demands Increased Transparency on Guantánamo Detainees From Obama Administration," Office of Time Scott, Senator for South Carolina, November 13, 2015.

73. Rosenberg, "Making Guantánamo Great Again."

74. Anne Speckhard, and Molly Ellenberg, "Trump vs Biden: Policies Countering Terrorism and Violent Extremism," TRENDS Research (2021). 


\section{Works Cited}

Adelman, Rebecca A. "'Safe, Humane, Legal, Transparent': State Visions of Guantánamo Bay." Reconstruction: Studies in Contemporary Culture (2013) https://search-ebscohost-com.login.

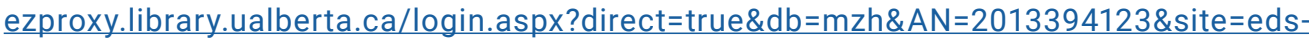
live\&scope $=$ site

Begg, Moazzam. "Full Address and Q\&A." OxfordUnion. April 25, 2017. Video, 57:23, https://www.youtube.com/watch?v=kOaoJg7mGHY\&ab_channel=0xfordUnion.

Borger, Julian. "CIA Gave Details of 9/11 Suspect's Secret Torture to Film-Makers, Lawyers Say." The Guardian (Manchester, UK), Feb. 22, 2019. https://www.theguardian.com/law/2019/feb/22/ ammar-al-baluchi-pre-trial-911-cia-guantanamo-bay-torture.

Conley, Julia. "Pentagon Secrecy around Covid at Guantánamo Is One More Reason to Shut the Prison, Say Senate Dems." Salon, Aug. 23, 2020. https://www.salon.com/2020/08/23/pentagon-secrecyaround-covid-at-Guantánamo-bay-is-one-more-reason-to-shut-the-prison_partner/.

Cossel, Benjamin. "PAO Teams with Media to Balance Transparency, Security." U.S. Army, February 28, 2011. https://www.army.mil/article/52536/pao_teams_with_media_to_balance_transparency security.

Epstein, Elisa. “Guantánamo's Ugly Taint on US Diplomacy.” Human Rights Watch, October 28, 2020. https://www.hrw.org/news/2020/02/13/Guantánamos-ugly-taint-us-diplomacy?fbclid=IwAR16tX OLGUAQGIsYiA9E9S9NwmMpgFZd8IDQkwEEYPqHbl__zyKcRVOUVfs.

Friedersdorf, Conor. "Dick Cheney Defends the Torture of Innocents." The Atlantic, December 15, 2014. https://www.theatlantic.com/politics/archive/2014/12/dick-cheney-defends-the-tortureinnocents/383741/.

Glazier, David W. "Destined for an Epic Fail: The Problematic Guantanamo Military Commissions." Ohio State Law Journal, no. 75 (2014). https://doi.org/10.2139/ssrn.2419656.

"Guantánamo Remains a Stain on America's Reputation." The Economist, January 14, 2017. https://www.economist.com/international/2017/01/14/guantanamo-remains-a-stain-onamericas-reputation.

Hafetz, Jonathan. "Torture and Transparency in the Military Commissions." Just Security, February 24, 2016. https://www.justsecurity.org/29505/torture-transparency-military-commissions/.

Hilal, Maha. "We can't just close Guantánamo Bay Prison, we also have to abolish the injustice that allowed it to exist." Business Insider, February 3, 2021. https://www.businessinsider.com/ guantanamo-bay-prison-abolish-biden-bush-administration-war-terror-2021-2.

Honigsberg, Peter J. "The Never-Ending Travesty of Guantanamo Bay." Interview by Sam Seder. The Majority Report w/ Sam Seder. January 19, 2020. Video, 46:28. https://www.youtube.com/ watch?v=_JAQOFNxndc\&ab_channel=TheMajorityReportw\%2FSamSeder.

Jacobson, Adam. "'The True Ugly Face of America': Al Qaeda's Propaganda Use of Guantánamo Bay and Implications for US Counterterrorism." Human Rights First (2015). https://papers.ssrn.com/sol3/ papers.cfm?abstract_id $=2614056$.

"Joint Letter Regarding Concerns about Lack of Transparency in Guantánamo Proceedings." Human Rights Watch, August 1, 2017. https://www.hrw.org/news/2017/08/01/joint-letter-regardingconcerns-about-lack-transparency-Guantánamo-proceedings.

Khan, Saadia H. "Transparency at Guantánamo, But Not Where It Counts." Human Rights First, August 11, 2015. https://www.humanrightsfirst.org/blog/transparency-Guantánamo-not-where-it-counts.

Kirby, John and Rosenberg, Carol. "The Ethics and Politics of Guantánamo Bay." Berkley Center. 
September 17, 2020. Video, 1:00:21. https://www.youtube.com/watch?v=6pHQ8ewCXoY\&ab_ channel=BerkleyCenter.

Knefel, John. "Transparency Is a Catch-22 at Guantánamo Bay." Inverse, June 6, 2016.

https://www.inverse.com/article/16544-transparency-is-a-catch-22-at-Guantánamo-bay.

Merriman, Justin. “GITMO Procedures Challenge Military 'Transparency'.” Trib Live, September 4, 2016.

https://archive.triblive.com/news/gitmo-procedures-challenge-military-transparency/.

“Military Commissions Media Invitation Announced CANCELLED for United States v. Majid Shoukat Khan Sentencing Hearing." U.S. Department of Defense, April 2, 2021. https://www.defense. gov/Newsroom/Advisories/Advisory/Article/2559856/military-commissions-media-invitationannounced-cancelled-for-united-states-v-m/.

Napoleon, Erin. "US Senators Concerned over Potential COVID-19 Outbreak at Guantánamo Bay." Jurist, May 28, 2020. https://www.jurist.org/news/2020/05/us-senators-concerned-over-potentialcovid-19-outbreak-at-guantanamo-bay/.

Newman, Zak. “Guantánamo Review Board: This Is Not What Transparency Looks Like.” American Civil Liberties Union, April 26, 2015. https://www.aclu.org/blog/national-security/detention/ Guantánamo-review-board-not-what-transparency-looks.

Patten, Rebecca M. “Searching for Transparency at Guantánamo Bay." American Nurse, October 11, 2019. https://www.myamericannurse.com/searching-for-transparency-at-Guantánamo-bay/.

Pfeiffer, Sacha. "Guantánamo Has Cost Billions; Whistleblower Alleges 'Gross' Waste." NPR, September 11, 2019. https://www.npr.org/2019/09/11/759523615/guant-namo-court-and-prison-have-costbillions-whistleblower-alleges-gross-waste.

Pradhan, Alka. "OPINION: A Momentous Victory for Justice and Transparency at Guantánamo." Al Jazeera America, October 5, 2014. http://america.aljazeera.com/opinions/2014/10/guantanamoforcefeedingabuwaeldhiab.html.

Rosenberg, Carol. "9/11 Hearings to Focus on Secrecy, Transparency." Miami Herald (Miami, FL), Oct. 14, 2012. https://www.miamiherald.com/news/nation-world/world/americas/guantanamo/ article1943596.html.

Rosenberg, Carol. “Making Guantánamo Great Again: The Prison’s Media Makeover.” Miami Herald (Miami, FL), Feb. 12, 2018.https://www.miamiherald.com/news/nation-world/world/americas/ guantanamo/article199576044.html.

Rosenberg, Carol. "New Conundrum At Guantánamo: Aging Detainees." The New York Times, Apr. 28, 2019. https://link.gale.com/apps/doc/A583753265/ GRNR?u=edmo69826\&sid = GRNR\&xid $=805 f 1131$

Rosenberg, Carol. "Pentagon Halts Plan to Vaccinate the 40 Detainees at Guantánamo Bay."

The New York Times, Jan. 31, 2021. https://link.gale.com/apps/doc/A650180942/ GRNR? $u=e d m o 69826 \&$ sid $=G R N R \& x i d=f 593455 e$

Rosenberg, Carol. "The Growing Culture of Secrecy at Guantánamo Bay." The New York Times, Apr. 4, 2020. https://www.nytimes.com/2020/04/04/us/politics/the-growing-culture-of-secrecy-atGuantánamo-bay.html.

Rosenberg, Carol. "Red Cross Faces Barriers in Visit to Guantánamo." The New York Times, Dec. 10, 2020. https://link.gale.com/apps/doc/A644416118/GRNR?u=edmo69826\&sid=GRNR\&xid=5fba48aa.

"Scott Demands Increased Transparency On Guantánamo Detainees From Obama Administration." Office of Tim Scott, Senator for South Carolina. November 13, 2015. https://www.scott.senate. gov/media-center/press-releases/scott-demands-increased-transparency-on-Guantánamo- 
detainees-from-obama-administration.

Schulz, David A. “Guantánamo Trials Should Be Open.” The New York Times, Apr. 19, 2012.

https://link.gale.com/apps/doc/A286882401/GRNR?u=edmo69826\&sid=GRNR\&xid=bd741c97.

Sheers, Aliana E. "Telltale Marks: Looking Beyond Censorship of Guantánamo.” Alpenglow: Binghamton University Undergraduate Journal of Research and Creative Activity 6, no. 1 (2020). https://orb.binghamton.edu/alpenglowjournal/vol6/iss1/6/.

Speckhard, Anne, and Molly Ellenberg. "Trump vs Biden: Policies Countering Terrorism and Violent Extremism." TRENDS Research (2021). https://trendsresearch.org/insight/trump-vs-bidenpolicies-countering-terrorism-and-violent-extremism/.

Spetalnick, Matt, Trevor Hunnicutt, and Phil Stewart. "Biden Launches Review of Guantánamo Prison, Aims to Close It before Leaving Office." Reuters, February 12, 2021. https://www.reuters.com/ article/us-usa-biden-Guantánamo-exclusive-idUSKBN2AC1Q4.

Swain, Elise. “It's Still Open: Will the Guantánamo Bay Prison Become a 2020 Issue?” The Intercept, March 3, 2019. https://theintercept.com/2019/03/03/guantanamo-bay-carol-rosenberg-intercepted/.

"Warren, Reed, Colleagues Seek Information on DOD Efforts to Prevent COVID-19 Outbreaks at Guantánamo Bay Prison: U.S. Senator Elizabeth Warren of Massachusetts." Office of U.S. Senator Elizabeth Warren of Massachusetts, May 28, 2020. https://www.warren.senate.gov/oversight/ letters/warren-reed-colleagues-seek-information-on-dod-efforts-to-prevent-covid-19-outbreaksat-Guantánamo-bay-prison.

Zemmouri, Moussa, Mohammed Ould Slahi, Ahmed Errachidi, Sami Al Hajj, Lakhdar Boumediane, Moazzam Begg, and Mansoor Adayfi. "An Open Letter to President Biden About Guantánamo." The New York Review of Books, Jan.29, 2021. https://www.nybooks.com/daily/2021/01/29/anopen-letter-to-president-biden-about-Guantánamo/. 